\title{
EFEKTIVITAS METODE FORWARD CHAINING PADA SISTEM PAKAR PENDETEKSI PENYAKIT KAMBING
}

\author{
Dwi Susanto ${ }^{1}$, Abdul Fadlil ${ }^{2}$, Anton Yudhana ${ }^{3}$ \\ E-mail : dwi1907048005@webmail.uad.ac.id ${ }^{1}$, fadlil@mti.uad.ac.id ${ }^{2}$, eyudhana@ee.uad.ac.id ${ }^{3}$ \\ Program Studi Magister Teknik Informatika, Universitas Ahmad Dahlan ${ }^{1,2}$ \\ Program Studi Teknik Elektro, Universitas Ahmad Dahlan ${ }^{3}$ \\ Jl. Prof Dr Soepomo SH, Umbulharjo, Yogyakarta, 55164
}

\begin{abstract}
Abstrak
Negara Indonesia merupakan negara yang beriklim tropis masyarakatnya sebagian besar adalah petani dan peternak. Ternak kambing merupakan ternak paling diminati masyarakat Indonesia mengingat modalnya relatif lebih kecil dibandingkan dengan ternak sapi. Mudahnya proses pemeliharaan ternak kambing tersebut, bisa dilakukan oleh siapa saja termasuk anggota keluarga sendiri. Penanganan penyakit pada ternak yang kurang cepat dan tepat mengakibatkan kerugian ekonomi yang cukup besar. Dalam hal bididaya dan ternak kambing sebagian besar peternak kurang mengetahui tentang pemeliharaan dan penanggulangan penya kit pada kambing. Biasanya para peternak kambing akan menyembelih hewan ternaknya ketika kambing terjangkit penyakit dan tidak tau bagaimana menanggulangi penyakitnya tersebut. Dengan adanya sistem pakar ini diharapkan dapat membantu para pemilik maupun peternak kambing menangani dan menanggulangi penyakit kambing dengan cepat berdasarkan gejala yang ditimbulkan. Dalam sistem pakar ini menggunakan metode Forward Chaining (pelacakan kedepan). Metode ini digunakan sebagai teknik mencari kesimpulan atau solusi dengan cara menguji aturan satu demi satu dalam urutan tertentu.
\end{abstract}

Kata kunci: Sistem Pakar, Basis Pengetahuan, Forward Chaining, Kambing.

\section{Pendahuluan}

Negara Indonesia merupakan negara beriklim tropis, masyarakatnya sebagian besar adalah petani dan peternak. Ternak kambing merupakan hewan paling diminati mengingat modalnya relatif lebih kecil dibandingkan dengan ternak sapi. Mudahnya proses pemeliharaan ternak kambing tersebut, bisa dilakukan oleh siapa saja termasuk anggota keluarga sendiri. kemampuan kambing yang dapat berkembang biak cepat mampu menghasilkan lebih dari satu ekor anak tiap melahirkan [1]. Ini merupakan salah satu usaha meningkatkan pengahasilan tambahan keluarga. Pemeliharaan kambing saat ini tidak hanya di desa, namun sudah menyebar ke seluruh masyarakat khususnya petani. Tingginya permintaan susu dan daging kambing yang selalu mengalami peningkatan, mengakibatkan muncul peternak kambing yang semakin banyak [2].

Produksi ternak kambing di pulau jawa merupakan salah satu potensi yang cukup besar. Di jawa timur populasi kambing sebesar 3 juta ekor lebih, menurut Dirjen (Direktorat Jenderal) peternakan dan kesehatan hewan tahun 2016, apalagi seluruh pulau jawa. Para peternak kambing dalam melakukan pemeliharaan ternaknya masih tradisional, cara penangggulanya pun masih memekai obat-obat tradisional. Penanganan dan penanggulanganya yang kurang cepat dan tepat mengakibatkan kerugian ekonomi yang tidak sedikit. Ini terjadi pada peternak kambing di pedesaan khususnya dan peternak lain pada umumnya [2].

Dalam hal bididaya dan ternak kambing sebagian besar peternak kurang mengetahui tentang pemeliharaan dan penanggulangan penyakit pada kambing. Biasanya para peternak kambing akan menyembelih hewan ternaknya ketika kambing terjangkit penyakit dan tidak tau bagaimana menanggulangi penyakitnya tersebut. Dengan sistem ini pemilik maupun peternak kambing dapat membantu menangani dan dan menanggulangi penyakit kambing dengan cepat berdasarkan gejala yang ditimbulkan [3].

Penelitian sebelumnya dilakukan oleh [2]mereka melakukan penelitian Sistem Pakar untuk Mendiaknosis Penyakit Pada Kambing dengan Metode Naive Bayes dan Certainty Factor. Dengan menggabungkan metode Naive Bayes dan Certainty Factor dapat mendeteksi penyakit kabing dengan cara menghitung derajat keyakinan penyakit dari hasil diagnosis yang dimasukan. Kedua metode tersebut akan menghitung gejala klinis yang muncul sehingga menghasilkan kesimpulan yang tepat. Penelitian selanjutnya oleh [4] melakukan Penerapan Sistem Pakar Untuk Diagnosa Autis dengan Metode Forward Chaining. Sistem ini belum sepenuhnya sempurna. Dengan 
mengumulkan data yang lebih kompleks pada basis pengetahuan akan lebih sempurna.

Kecerdasan buatan adalah salah satu ilmu dalam bidang komputer yang melibatkan perangkat komputer [5]. Sistem bekerja secara cerdas seperti layaknya manusia [6]. Perangkat lunak dan perangkat keras sebagai piranti pengembangan sistem ini sehingga mampu menggantikan peranan manusia. Perangkat komputer tersebut menirukan peranan atau aktifitas manusia seperti penalaran, penglihatan, pembelajaran, pemecahan masalah, pemahaman bahasa alami dan lain sebagainya [2].

Sistem pakar adalah sistem yang mengadopsi pengetahuan manusia kemudian diimplementasikan pada perangkat komputer sebagai solusi untuk menyelesaikan masalah sebagaiman seorang yang dilakukan pakar atau dokter [7]. Sistem ini memiliki beberapa komponen utama, antara lain basis pengetahuan, tampilam antar muka pengguna, akuisisi pengetahuan dan mesin inferensi. Yang paling penting dalam sistem pakar ini adalah fasilitas penjelasan (explanation fancility). Komponen tersebut hanya dimiliki oleh sistem pakar ini [1].

Struktur sistem pakar terdapat dua bagian utama, yaitu lingkunga konsultasi dan pengembangan. sistem pakar builder melakukan lingkungan pegembangkan untuk membangun komponen. Pengetahuan tersebut kemudian dimasukkan ke dalam basis pengetahuan. User atau peternak menggunakan lingkungan konsultasi untuk mendapatkan pengetahuan atau informasi serta solusi pakar [8]. Komponen tersebut dapat dilihat pada Gambar 1.

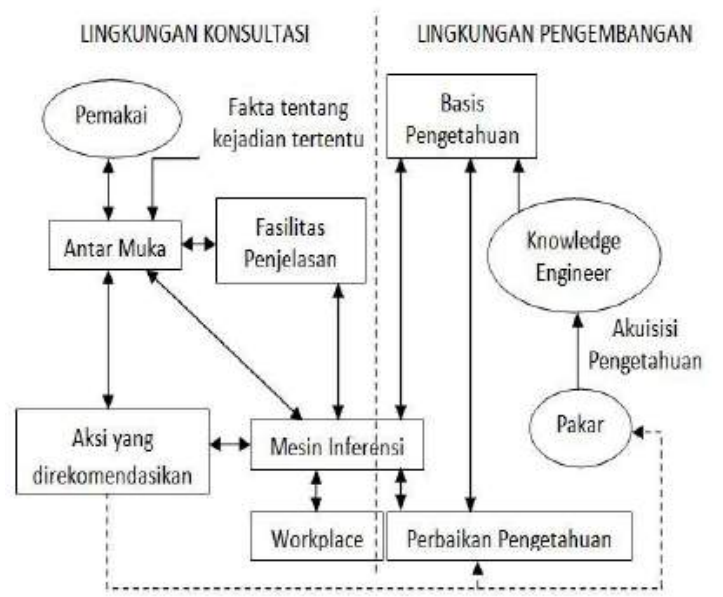

Gambar 1. Struktur Sistem Pakar

\section{Metode Penelitian}

Metode yang digunakan dalam sistem pakar ini adalah Forward Chaining. Metode ini bekerja mendapatkan hasil kesimpulan yang dimulai dengan menelusuri fakta yang dimasukan [9]. Metode Forward chaining disebut juga ranut maju. Metode ini sangat cocok digunakan untuk menyelesaikan masalah dengan peramalan (prognosis) dan pengendalian (controlling). Aturan yang sudah dibuat kemudian diuji satu demi satu dalam urutan tertentu. Inferensi dimulai dengan informasi yang tersedia dan baru konklusi diperoleh. Metode ini melakukan pencarian dari suatu masalah kepada solusinya yang merupakan grup dari multiple inferensi. Jika klausa premis sesuai dengan situasi atau bernilai benar, maka proses akan menghasilkan konklusi. Forward chaining dapat digunakan jika suatu aplikasi menghasilkan pohon (tree) yang lebar dan tidak dalam [3]. Proses Forward chaining dapat dilihat pada Gambar 2.

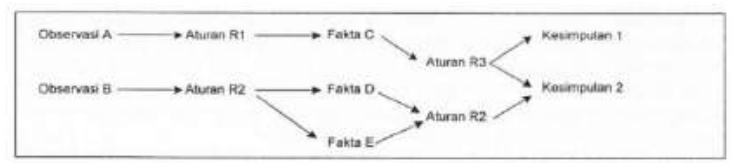

Gambar 2. Proses Forward Chaining (Pelacakan Kedepan)

Untuk menentukan prosentase ketepatan dalam proses pengklasifikasian terhadap data testing perlu diuji tingkat akurasinya. [3]. Selanjutnya tingkat akurasi dapat dihitung dengan rumus:

Akurasi $=\frac{\Sigma \mathrm{n}}{\Sigma \mathrm{nt}} \times 100 \%$

Keterangan :

$\Sigma \mathrm{n}=$ Total hasil benar

$\Sigma$ nt $=$ Total seluruh data (salah dan benar)

Pengetahuan dalam kaidah penulisan produksi direpresentasikan dalam bentuk :

JIKA [premis] MAKA [konklusi]

JIKA [kondisi] MAKA [aksi]

JIKA [antecedent] MAKA [konsekuen]

Forward chaining melakukan proses pencarian dari suatu masalah menuju kesimpulanya. Jika klausa kondisi sesuai dengan situasi, maka proses akan memeberikan kesimpulan [10]. Kinerja forward chaining dapat dilihat pada Gambar 3. 


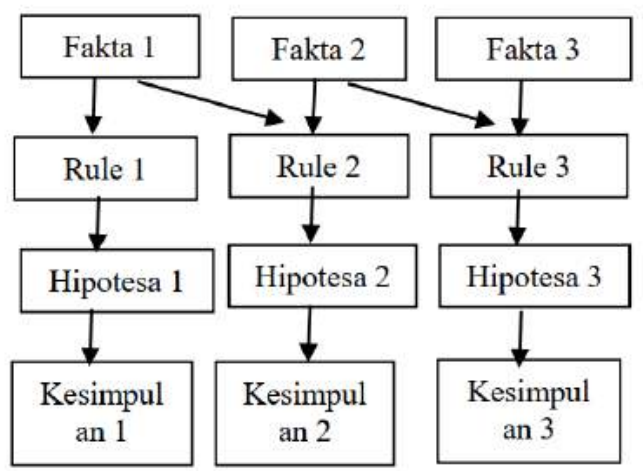

Gambar 3. Kinerja Forrward Chaining

Basis pengetahuan mengandung pengetahuan untuk pemahaman formulasi dan penyelesaian masalah. Fakta merupakan informasi tentang obyek dalam area permasalahan tertentu, seperti jenis penyakit dan gejala yang dialami [4]. Fakta tersebut dapat di lihat pada Tabel 1 dan Tabel 2.

Tabel 1. Data Penyakit

\begin{tabular}{|c|l|}
\hline $\begin{array}{c}\text { Kode } \\
\text { Penyakit }\end{array}$ & \multicolumn{1}{c|}{ Nama Penyakit } \\
\hline P01 & Cacingan \\
\hline P02 & Mencret (Diare) \\
\hline P03 & Kudis atau Kurap (Scabies) \\
\hline P04 & $\begin{array}{l}\text { Kembung (Tympany atau } \\
\text { Bloat) }\end{array}$ \\
\hline P05 & Mata Beleken (Pink Eye) \\
\hline P06 & Keracunan \\
\hline P07 & Tetanus \\
\hline P08 & Antraks \\
\hline
\end{tabular}

Data gejala yang digunakan dalam siatem pakar deteksi penyakit kambing ini sejumlah 21 macam gejala. Gejala tersebut dapat dilihat pada Tabel 2.

Tabel 2. Data Gejala

\begin{tabular}{|c|l|}
\hline $\begin{array}{c}\text { Kd } \\
\text { Gejala }\end{array}$ & \multicolumn{1}{c|}{ Nama Gejala } \\
\hline G01 & Ternak tampak lesu, lemah, pucat \\
\hline G02 & Nafsu makan berkurang \\
\hline G03 & $\begin{array}{l}\text { Kambing diare, Perut membesar } \\
\text { dan bulu berdiri dan kusam }\end{array}$ \\
\hline G04 & $\begin{array}{l}\text { Kotoran kambing berwarna hijau } \\
\text { muda, kemerahan, atau kehitaman }\end{array}$ \\
\hline G05 & $\begin{array}{l}\text { Kulit bercak-bercak merah yang } \\
\text { membentuk bisul sehingga } \\
\text { mengalami kekakuan, penebalan, } \\
\text { dan bersisik }\end{array}$ \\
\hline G06 & Ternak kurus \\
\hline
\end{tabular}

\begin{tabular}{|c|l|}
\hline G07 & $\begin{array}{l}\text { Ternak mengosok-gosokan } \\
\text { kulitnya ke kandang karena gatal } \\
\text { dan bulu terlihat rontok }\end{array}$ \\
\hline G08 & Ternak sulit bernafas \\
\hline G09 & $\begin{array}{l}\text { Perut bagian kiri terlihat besar, } \\
\text { jika ditepuk akan berbunyi seperti } \\
\text { gendang }\end{array}$ \\
\hline G10 & Ternak merasa gelisah \\
\hline G11 & $\begin{array}{l}\text { Ternak jatuh dan susah bangun } \\
\text { lagi }\end{array}$ \\
\hline G12 & Mata berair dan berkedip-kedip \\
\hline G13 & $\begin{array}{l}\text { Mata berwarna merah dan } \\
\text { membengkak }\end{array}$ \\
\hline G14 & $\begin{array}{l}\text { Muncu borok pada selaput bening } \\
\text { hingga mengalami kebutaan }\end{array}$ \\
\hline G15 & Ternak kejang-kejang \\
\hline G16 & $\begin{array}{l}\text { Mulut berbusa, Selaput lendir } \\
\text { mata berwarna kebiru-biruan }\end{array}$ \\
\hline G17 & Kotoran bercampur darah \\
\hline G18 & Ternak mengalami demam tinggi \\
\hline G19 & Sebagian tubuhnya menjadi kaku \\
\hline G20 & $\begin{array}{l}\text { Pembengkakakan kelenjar dada, } \\
\text { dada penuh bisul }\end{array}$ \\
\hline G21 & $\begin{array}{l}\text { Mengeluarkan darah dari telinga, } \\
\text { mulut, dan anus }\end{array}$ \\
\hline
\end{tabular}

Tabel relasi data penyakit dan gejala, didapatkan tabel keputusan yang isinya relasi atau hubungan antara penyakit dengan gejalanya. Relasinya dapat dilihat pada Tabel 3 relasi gejala dan penyakit pada kambing.

Tabel 3. Relasi Data Penyakit dan Gejala

\begin{tabular}{|c|l|}
\hline Kd Penyakit & \multicolumn{1}{c|}{ Kd Gejala } \\
\hline P01 & G01,G02,G03 \\
\hline P02 & G01,G04 \\
\hline P03 & G05,G06,G07 \\
\hline P04 & G08,G09,G10,G11 \\
\hline P05 & G12,G13,G14 \\
\hline P06 & G15,G16,G17 \\
\hline P07 & G15,G18,G19 \\
\hline P08 & G20,G21 \\
\hline
\end{tabular}

Pohon keputusan digunakan untuk membangun sebuah sisten pakar, didalam pohon keputusan akan dicari solusi akhir setiap pemeriksaan. Pohon keputusan ini mempermudah untuk menyusun basis pengetahuan seperti yang tertera pada Gambar 4. 


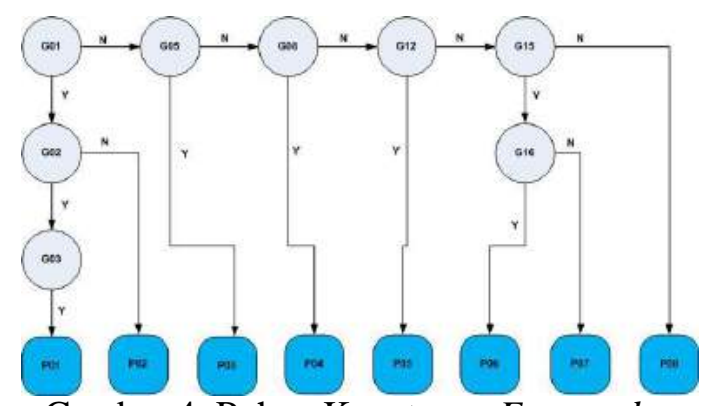

Gambar 4. Pohon Keputusan Forward Chaining

Gambaran Umum Sistem digunakan untuk deteksi penyakit kambing dengan bahasa pemrograman yang dipakai PHP dan MySQL [11]. Sistem ini menerima input dari konsultasi user berupa gejala yang di tampilkan pada tampilan konsultasi. Sebelum melakukan konsultasi, user mengisikan data pribadi antara lain nama, alama, jenis kelamin dan email. Pada metode Forward Chaining ini gejala akan diolah oleh sistem kemudian menghasilakan kesimpulan atau solusi. Berdasarkan data pada basis pengetahuan, relasi tabel di buat sesuai dengan data yang ada [12].

\section{Hasil dan Pembahasan}

Hasil skenario pengujian dengan metode Forward Chaining untuk deteksi penyakit kambing dilakukan pada 8 jenis penyakit seperti ditujukan pada tabel 3. Semua model pertanyaan dari user akan diuji oleh sistem. Dengan menghitung hasil dari pengujian tersebut akan dihasilkan prosentase keberhasilan dalam mendeteksi penyakit kambing. Perbandingan hasil pengujian penyakit kambing dengan metode Forward Chaining dapat dilihat pada tabel 4 dan 5.

Tabel 4. Pengujian pada Model Pertanyaan 1

\begin{tabular}{|c|c|c|}
\hline $\begin{array}{c}\text { Kode } \\
\text { Gejala }\end{array}$ & Gejala yang Masuk & $\begin{array}{c}\text { Jawaban } \\
\text { User }\end{array}$ \\
\hline G01 & $\begin{array}{c}\text { Ternak tampak lesu, } \\
\text { lemah, pucat }\end{array}$ & Benar \\
\hline G02 & $\begin{array}{c}\text { Nafsu makan } \\
\text { berkurang }\end{array}$ & Benar \\
\hline G03 & $\begin{array}{c}\text { Kambing diare, Perut } \\
\text { membesar dan bulu } \\
\text { berdiri dan kusam }\end{array}$ & Benar \\
\hline
\end{tabular}

$$
\begin{aligned}
\text { Hasil pengujian } & =\frac{\sum \mathrm{n}}{\sum \mathrm{nt}} \times 100 \% \\
& =\frac{3}{3} \times 100 \% \\
& =100 \%
\end{aligned}
$$

Dari contoh pengujian 1 hasil analisis tersebut menunjukan tingkat akurasi pendeteksi penyakit yaitu sebesar $100 \%$.

Tabel 5. Pengujian pada Model Pertanyaan 2

\begin{tabular}{|c|c|c|}
\hline $\begin{array}{c}\text { Kode } \\
\text { Gejala }\end{array}$ & Gejala yang Masuk & $\begin{array}{c}\text { Jawaban } \\
\text { User }\end{array}$ \\
\hline G05 & $\begin{array}{c}\text { Kulit tampak bercak- } \\
\text { bercak merah yang } \\
\text { membentuk bisul } \\
\text { sehingga mengalami } \\
\text { kekakuan, penebalan, } \\
\text { dan bersisik. }\end{array}$ & Tidak \\
\hline G06 & Ternak kurus & Benar \\
\hline G07 & $\begin{array}{c}\text { Ternak mengosok- } \\
\text { gosokan kulitnya ke } \\
\text { kandang karena gatal } \\
\text { dan bulu terlihat } \\
\text { rontok }\end{array}$ & Benar \\
\hline Hasil pengujian $=\frac{\Sigma \mathrm{n}}{\sum \mathrm{nt}} \times 100 \%$ \\
$=\frac{2}{3} \times 100 \%$ \\
$=66,7 \%$
\end{tabular}

Dari contoh pengujian 2 hasil analisis tersebut menunjukan tingkat akurasi pendeteksi penyakit yaitu sebesar $66,7 \%$.

\subsection{Pengujian Dengan Sistem}

1. Menu Utama Sistem Pakar Diagnosa Penyakit Kambing.

Menu utama sistem pakar digunakan untuk tampilan utama dari sistem pakar. Dapat dilihat pada Gambar 5 dibawah ini :

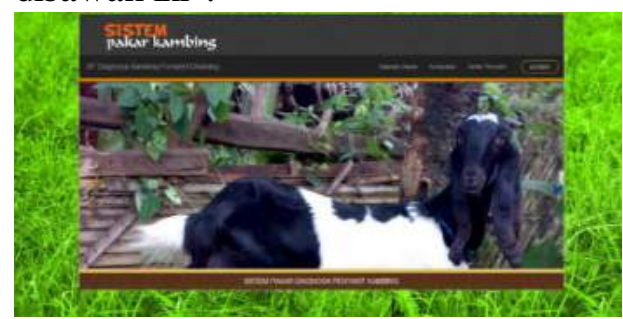

Gambar 5. Menu utama sistem pakar kambing

2. Menu Admin

Menu admin digunakan untuk login admin yaitu mengelola sistem pakar. Dapat dilihat pada Gambar 6 dibawah ini: 


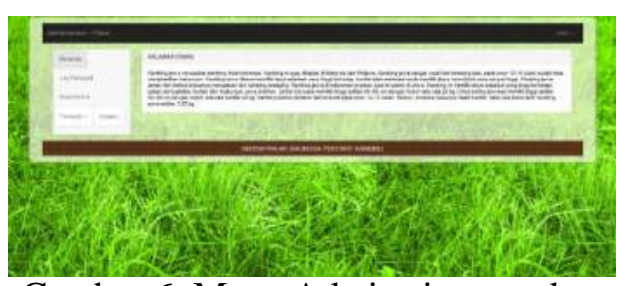

Gambar 6. Menu Admin sistem pakar kambing

3. Menu entri data penyakit

Menu ini digunakan untuk memasukan data penyakit kambing. Dapat dilihat pada Gambar 7 dibawah ini:

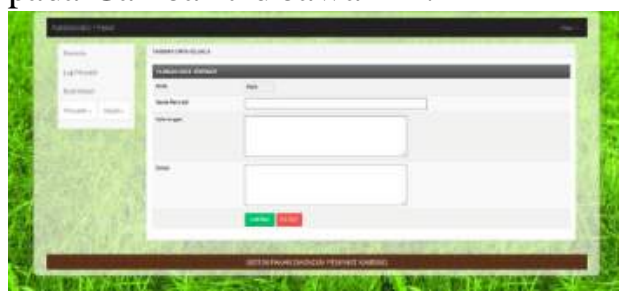

Gambar 7. Menu entri data penyakit

4. Menu entri data gejala

Menu ini digunakan untuk memasukan data gejala kambing. Dapat dilihat pada Gambar 8 dibawah ini:

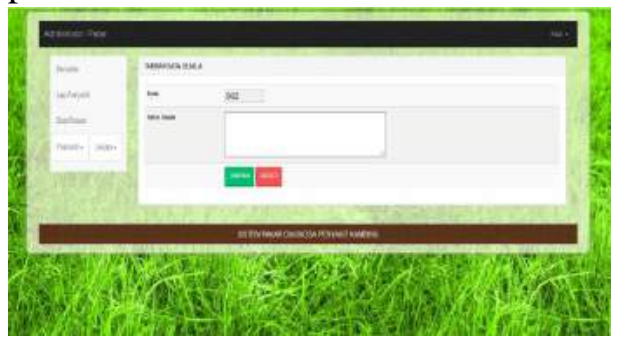

Gambar 8. Menu entri data gejala

5. Menu relasi penyakit dan gejala Menu ini digunakan untuk memasukan data relasi penyakit dan gejala kambing. Dapat dilihat pada Gambar 9 dibawah ini:

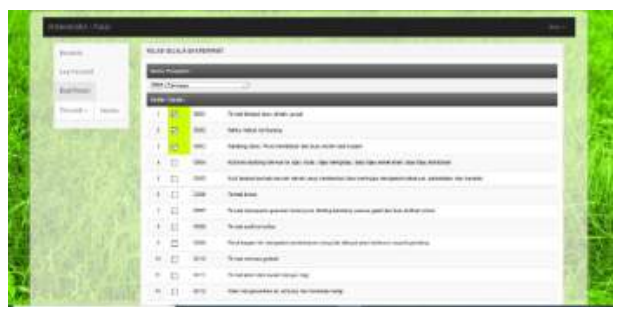

Gambar 9. Menu relasi dan gejala

6. Menu laporan konsultasi penyakit Menu ini digunakan untuk menampilkan hasil konsultasi penyakit kambing. Dapat dilihat pada Gambar 10 dibawah ini:

\section{E-ISSN : 2549-0796}

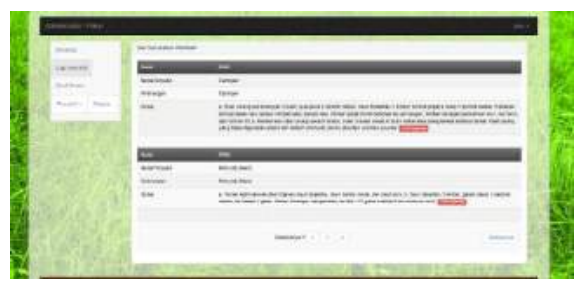

Gambar 10. Menu laporan penyakit

7. Menu daftar konsultasi

Menu ini digunakan untuk user sebagai konsultasi sistem pakar. Dapat dilihat pada Gambar 11 dibawah ini:

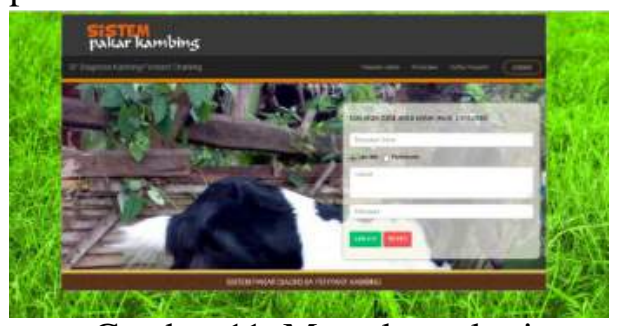

Gambar 11. Menu konsultasi

8. Menu tampil konsultasi

Menu ini digunakan tampil konsultasi. Dapat dilihat pada Gambar 12 dibawah ini:

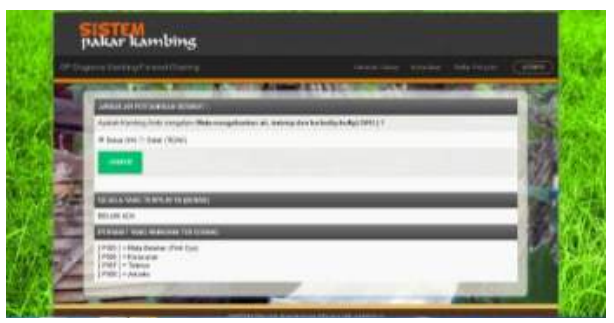

Gambar 12. Menu konsultasi.

9. Menu hasil diagnosa.

Menu ini digunakan tampil hasil diagnosa. Dapat dilihat pada Gambar 13 dibawah ini:

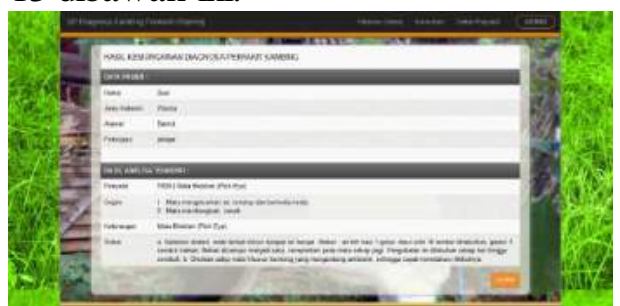

Gambar 13. Hasil diagnosa.

\section{Kesimpulan}

Kesimpulan dari hasil penelitian Evektivitas metode Forward Chaining Sistem Pakar Pendeteksi Penyakit Kambing maka dapat diambil kesimpulan bahwa metode Forward Chaining ini lebih mudah karena melibatkan penelusuran rule gejala yang ditimbulkan oleh hewan ternak. Mudah 
dipahami oleh user sehingga dapat membantu masyarakat dalam mengenali berbagai macam gejala, jenis penyakit dan solusi cara menangani penyakit kambing. Metode ini melibatkan penulisan rule untuk mengatur sub goal. Fakta penyakit, gejala, dan solusi merupakan basis pengetahuan dalam sistem ini. Jumlah penyakit yang diolah dalam siatem pakar diagnosa penyakit kambing ini adalah 8 macam penyakit dan 21 gejala.

Projek kedepan yang akan kita kembangkan adalah mengimplementasikan sistem pakar tersebut menggunakan bahasa pemrograman java maupun phyton sehingga dapat di di jalankan pada smart phone. Dengan metode Forward Chaining diharapkan sistem lebih mudah di jalankan dan dipahami oleh user atau peternak. Selain dengan metode tersebut bisa juga menggunakan metode yang lain misalkan Case Based Reasoning dan lain sebangainya. Eksplorasi dari pengetahuan memiliki mekanisme yang berbeda antara metode Forward Chaining dan metode yang lain.

\section{Daftar Pustaka}

[1] D. Susanto et al., "Analisis Metode Forward Chaining pada Sistem Pakar Pendeteksi Penyakit Kambing," no. Sinaptika, 2019.

[2] W. R. Ferdiansyah, L. Muflikhah, and S. Adinugroho, "Sistem Pakar Diagnosis Penyakit Pada Kambing Menggunakan Metode Naive Bayes dan Certainty Factor," J. Pengemb. Teknol. Inf. dan Ilmu Komput., vol. 2, no. 2, pp. 451458, 2018.

[3] I. Apriliya and I. Wahyuni, "Sistem Diagnosis Penyakit pada Kambing Menggunakan Metode Forward Chaining," J. Ilm. Teknol. Inf. Asia, vol. 11, no. 2, p. 113, 2017, doi: 10.32815/jitika.v11i2.190.

[4] R. Rachman, "Penerapan Sistem Pakar Untuk Diagnosa Autis Dengan Metode Forward Chaining," J. Inform., vol. 6, no. 2, pp. 218-225, 2019, doi: 10.31311/ji.v6i2.5522.

[5] Budiarto, "Perancangan Sistem Pakar Diagnosa Potensi Serangan Stroke
Menggunakan Metode Fuzzy," Pelita Inform. Budi Darma, no. 1, pp. 69-76, 2015.

[6] J. Elektronik et al., "Aplikasi Sistem Pakar Diagnosa Penyakit Umum Pada Manusia Berbasis Web," vol. 7, no. 2, pp. 59-67, 2018.

[7] Z. Yunizar, "Sistem Pakar Diagnosa Penyakit THT Menggunakan Metode Bayes," Maj. Ilm. Univ. Almuslim, vol. 11, no. October, 2019.

[8] Minarni and I. Warman, "Sistem Pakar Identifikasi Penyakit Tanaman Padi Menggunakan Case-Based Reasoning," Semin. Nas. Apl. Teknol. Inf., no. 5 Agustus 2017 ISSN: 1907 - 5022, pp. 28-32, 2017.

[9] G. A. D. Sugiharni and D. G. H. Divayana, "Pemanfaatan Metode Forward Chaining Dalam Pengembangan Sistem Pakar Pendiagnosa Kerusakan Televisi Berwarna," J. Nas. Pendidik. Tek. Inform., vol. 6, no. 1, p. 20, 2017, doi: 10.23887/janapati.v6i1.9926.

[10] D. T. Yuwono, A. Fadlil, and S. Sunardi, "Penerapan Metode Forward Chaining Dan Certainty Factor Pada Sistem Pakar Diagnosa Hama Anggrek Coelogyne Pandurata," Klik - Kumpul. J. Ilmu Komput., vol. 4, no. 2, p. 136, 2017, doi: $10.20527 / \mathrm{klik} . v 4 i 2.89$.

[11] I. M. Sari and F. Thalib, "Pembuatan Aplikasi Sistem Pakar Berbasis Web Untuk Diagnosis Penyakit Infeksi Yang Disebabkan Oleh Bakteri Dan Virus," $J$. Ilm. Inform. Komput., vol. 24, no. 1, pp. 1-13, 2019, doi: 10.35760/ik.2019.v24i1.1985.

[12] A. D. dkk Jatmiko, "Analisis Dan Implementasi Sistem Pakar Dengan Metode Case Based Reasoning Dan Rule Based Reasoning (Studi Kasus: Diagnosis Penyakit Demam Berdarah)," e-Proceeding Eng., vol. 4, no. 2, pp. 3269-3276, 2017. 